\title{
Analisis Kesulitan Calon Guru Sekolah Dasar Dalam Menyelesaikan Soal Pemecahan Masalah Matematis Berdasarkan Prosedur Newman
}

\author{
Nia Kania \\ Program Studi Pendidikan Matematika, Universitas Majalengka, Majalengka, Indonesia \\ niakania@unma.ac.id \\ Zaenal Arifin * \\ Program Studi Pendidikan Matematika Universitas Majalengka, Majalengka, Indonesia \\ Penulis Korespondensi, zaenalarifin@unma.ac.id
}

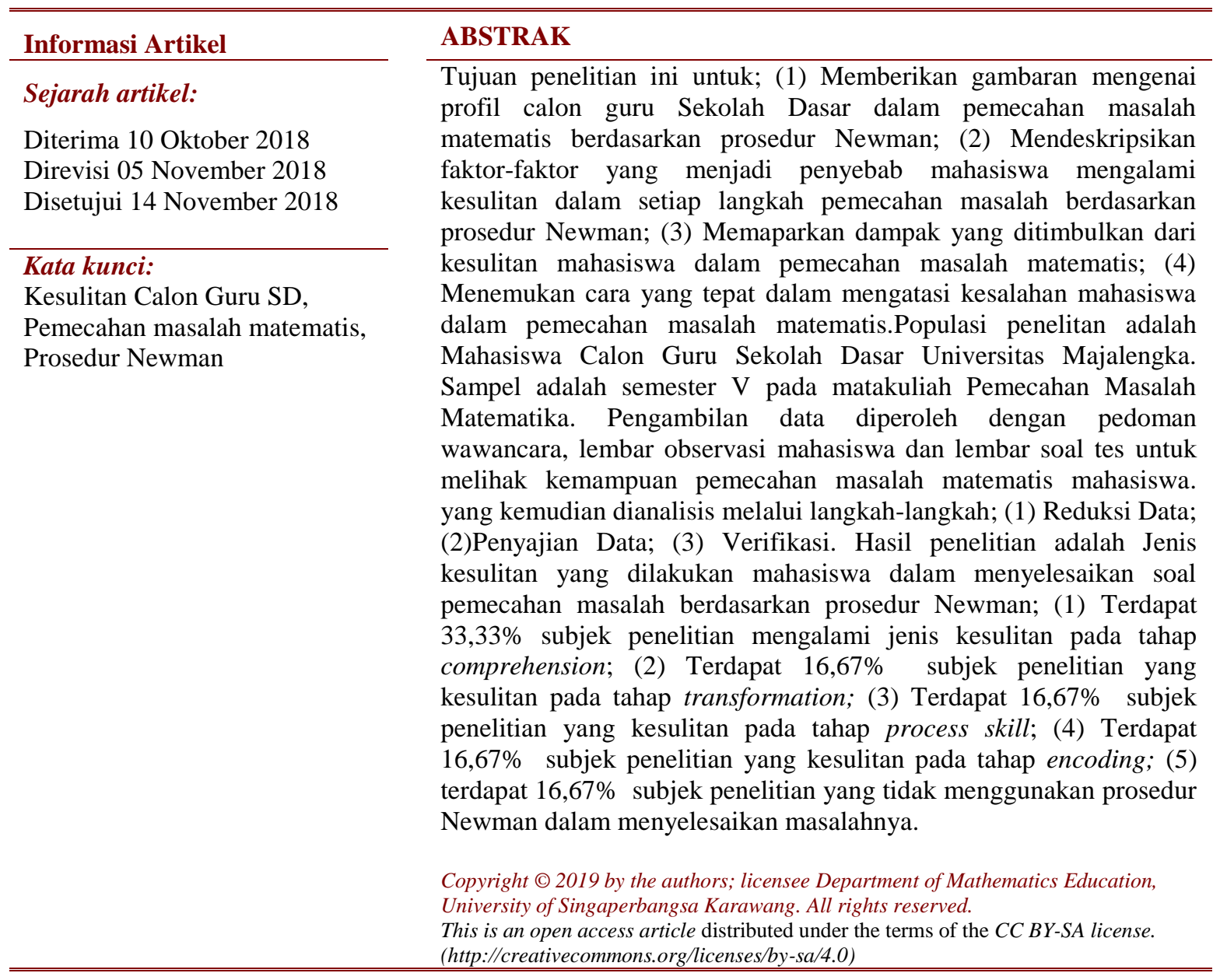

\section{PENDAHULUAN}

Matematika merupakan disiplin ilmu yang memiliki struktur dan keterkaitan yang kuat dan jelas antara konsep yang satu dengan konsep yang lain dan ini memungkinkan peserta didik terampil bertindak atas dasar pemikiran yang rasional dan logis dalam menyelesaikan masalah. Sebagaimana pendapat Verschaffel dan Corte (Turmudi, 2008), "mathematics as human sensemaking and problem solving activity" Hal ini menjadikan matematika sebagai disiplin ilmu yang disampaikan sejak pendidikan dasar hingga Perguruan Tinggi. Program Studi Pendidikan Guru Sekolah Dasar (PGSD) terdapat matakuliah Pemecahan Masalah 
Matematika yang wajib ditempuh bagi mahasiswa dengan bobot 3 sks yang disampaikan pada semester V. Pada mata kuliah ini, mahasiswa dituntut memiliki kemampuan pemecahan masalah matematika dalam menyelesaikan masalah-masalah matematika.

Menurut National Council of Teacher of Mathematics (NCTM) dan Badan Standar Nasional Pendidikan (BNSP) salah satu tujuan pembelajaran matematika adalah pemecahan masalah matematis. Lebih lanjut Branca (Alam \& Pathudin, 2002) menegaskan bahwa kemampuan pemecahan masalah adalah merupakan tujuan umum dan kemampuan dasar dalam pembelajaran matematika. Hal ini di dukung menurut Abdullah (2000), adalah satu tujuan utama belajar matematika adalah bahwa siswa mampu memecahkan masalah.

Pemecahan masalah matematika adalah proses yang menggunakan kekuatan dan manfaat matematika dalam menyelesaikan masalah yang juga merupakan metode penemuan solusi melalui tahap-tahap pemecahan masalah. Kemampuan pemecahan masalah termasuk kedalam kemampuan berpikir tingkat tinggi dalam menyelesaikan masalah tidak rutin, berpikir dinamis dan merekonstruksi kembali pengetahuan yang telah diperoleh sebelumnya. Hal ini diperkuat pendapat Bahar (2015) yang mengatakan bahwa pemecahan masalah disebut sebagai proses berpikir tingkat tinggi yang terdiri dari kemampuan intelektual utama dan proses kognitif.

Pada kenyataannya, survey yang dilakukan oleh JICA Tehnical Cooperation Project for Development of Science and Mathematics Teaching for Primary and Secondary Education in Indonesia (IMSTEP-JICA) pada tahun 1999 menemukan hasil bahwa salah satu kegiatan dalam matematika yang dipandang sulit oleh siswa dalam belajar dan guru dalam mengajar adalah pemecahan masalah matematis. Rendahnya kemampuan pemecahan masalah matematis dapat dilihat dari hasil tes Programme for International Student Assessment (PISA). Distribusi kemampuan matematika siswa dalam PISA pada tahun 2012 adalah level 1 (sebanyak 49,7\% siswa), level 2 (25,9\%), level $3(15,5 \%)$, level $4(6,6 \%)$, dan level 5-6 (2,3\%) (OECD, 2013). Pada level 1 ini siswa hanya mampu menyelesaikan persoalan matematika yang memerlukan satu langkah. Pada level 2, yaitu mampu menerapkan pemecahan masalah sederhana, menafsirkan dan menyampaikannya. Secara proporsional, dari setiap 100 siswa di Indonesia hanya sekitar 3 siswa yang mencapai level 5 - 6. Senada dengan hal tersebut, hasil Trends in International Mathematics and Science Study (TIMSS) tahun 2011 dalam bidang matematika, Indonesia menempati peringkat 38 dari 45 negara. Tentu hal ini bukan merupakan posisi yang menggembirakan.

Gambaran kondisi siswa Indonesia tersebut menggambarkan pula kondisi Mahasiswa Calon Guru Sekolah Dasar di Universitas Majalengka. Hal ini sesuai dengan observasi pendahuluan, bahwa pada tingkatan mahasiswa pun, mengalami kesulitan dalam mengembangkan kemampuan pemecahan masalah matematis. Untuk membantu mendeskripsikan kemampuan pemecahan masalah maka digunakan tahapan analisis Newman yang dikembangkan oleh Anne Newman pada tahun 1977. Prosedur Newman merupakan tahapan untuk memahami dan menganalisis bagaimana mahasiswa memecahkan masalah matematis melalui lima tahapan dalam pemecahan masalah matematika, yaitu a) membaca masalah (reading), b) memahami masalah (comprehension), c) mentransformasikan masalah (transformation), d) keterampilan proses (process skills), dan e) penulisan jawaban akhir (encoding).

Berdasarkan latar belakang masalah yang telah diuraikan di atas, maka rumusan masalah dalam penelitian ini adalah sebagai berikut : (1) Bagaimana profil calon guru Sekolah Dasar dalam pemecahan masalah matematis berdasarkan prosedur Newman?; (2) Bagaimana faktor-faktor yang menjadi penyebab mahasiswa mengalami kesulitan dalam setiap langkah pemecahan masalah berdasarkan prosedur Newman?; (3) Bagaimana 
dampak yang ditimbulkan dari kesulitan mahasiswa dalam pemecahan masalah matematis?; (4) Bagaimana cara mengatasi kesalahan mahasiswa dalam pemecahan masalah matematis?

\section{METODE}

Penelitian ini menggunakan mix method atau dinamakan penelitian campuran. Dimanapenelitiingin mengetahui kemampuan pemecahan masalah mahasiswaberdasarkan pemecahan masalah. Pada penelitian ini, model penelitian yang digunakan adalah model concurrent embedded (campuran tidak berimbang). Metode kombinasi model atau desain concurrent embedded adalah metode penelitian yang menggabungkan antara metode penelitian kualitatif dan kuantitatif dengan cara mencampur kedua metode tersebut secara tidak seimbang (Sugiyono, 2013). Pada penelitian ini, metode kualitatif merupakan metode primer karena bobotnya lebih tinggi, dan metode kuantitatif merupakan metode sekunder.

Adapun langkah-langkah penelitian kombinasi model concurrent embedded dapat dilihat melalui Gambar 1 di bawah ini.

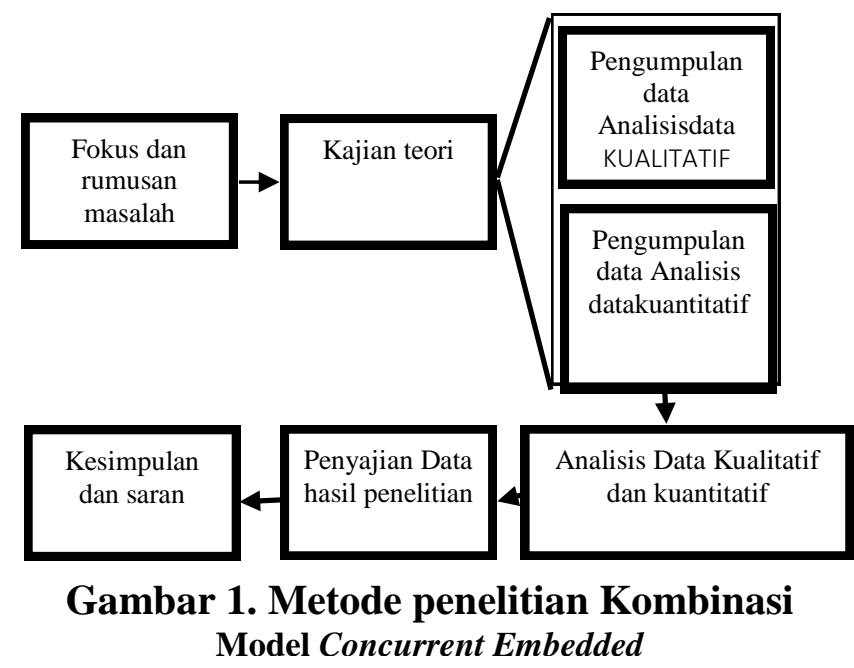

Teknik analisis data yang digunakan dalam penelitian ini melalui langkah-langkah menurut Miles dan Huberman (Sugiyono, 2013) terdiri atas:

(1) Reduksi Data (data reduction)

Mereduksi data berarti merangkum, memilih hal-hal pokok, memfokuskan pada halhal penting, dicari tema dan polanya dan polanya dan membuang yang tidak perlu. Data yang telah direduksi akan memberikan gambaran yang lebih jelas, dan mempermudah peneliti untuk melakukan pengumpulan data selanjutnya dan mencarinya bila perlu.

(2) Penyajian Data (data display)

Setelah data direduksi, maka langkah selanjutnya adalah menyajikan data. Untuk data kualitatif, penyajian data bisa dilakukan dengan uraian singkat, bagan, hubungan antar kategori dan sejenisnya, sedangkan data kuantitatif di sajikan dalam perhitungan statistik.

(3) Verifikasi (conclusion drawing)

Data yang dianalisis dalam penelitian ini adalah hasil dari wawancara, observasi dan tes hasil belajar matematika mahasiswa. 


\section{HASIL DAN PEMBAHASAN}

1) Subjek penelitian $1\left(M_{1}\right)$

Subjek penelitian $1\left(M_{1}\right)$ dari 3 butir soal yang dikerjakan, dan semuanya tidak tuntas dikerjakan oleh $M_{1}$, diantaranya adalah soal nomor 1 , 3, dan 5. Pemilihan $M_{1}$ sebagai subjek penelitian adalah mewakili dari kelompok kemampuan rendah pada kelompok kelas. Soal yang akan dianalisis adalah soal nomor 1, dengan alasan bahwa soal nomor 1 adalah soal dengan jumlah paling banyak mahasiswa yang jawabannya benar diantara soal yang lainnya. Jadi peneliti ingin mengetahui secara tepat letak kesulitan $M_{1}$ dalam mengerjakan soal nomor 1 . Peneliti ingin menganalisis apakah memang $M_{1}$ tidak tahu langkah apa yang harus dilakukan untuk memproses jawaban atau ada alasan lainnya.

Setelah diperoleh hasil analisis jawaban tertulis, analisis data wawancara dan observasi, selanjutnyadilakukan perbandingan untuk mengetahui valid tidaknya data yang diperoleh. Berikut adalahrangkuman kemampuan pemecahan masalah matematis mahasiswa pada subjek penelitian 1 .

Tabel 1. Triangulasi dari Hasil Jawaban, Wawancara dan Observasi terhadap Subjek Penelitian 1

\begin{tabular}{llllr}
\hline Hasil Tes Tertulis & Hasil Wawancara & Hasil Observasi & \\
\hline Subjek penelitian kesulitan & $M_{1}$ berpikir bahwa 68 buah & $M_{1}$ telah & mencoba \\
pada tahapan & adalah jumlah semua kaki & melakukan & langkah \\
Comprehension, dimana & meja tiga dan meja empat, & Newman, namun keliru \\
$M_{1}$ tidak dapat memahami & sehingga $M_{1}$ keliru dalam & menyatakan hal ditanyakan \\
dengan baik permasalahan & memahami apa yang & dari soal & \\
yang ada, $M_{1}$ tidak dapat & diketahui dan apa yang & \\
menentukan dengan benar & ditanyakan. & & & \\
apa yang diketahui dari & & & & \\
soal. & & & & \\
\hline
\end{tabular}

\section{Kesimpulan}

Pada soal nomor 1 dapat dibuat kesimpulan bahwa $M_{1}$ telah menerapkan langkah-langkah prosedur Newman dalam mengerjakan soal pemecahan masalah matematika. Namun, $M_{1}$ mengalami kesulitan dalam menyelesaikan soal nomor 1 adalah pada tahap memahami soal/Comprehension.

\section{2) Subjek Penelitian $2\left(M_{2}\right)$}

Subjek penelitian $2\left(M_{2}\right)$ dari 5 butir soal yang dikerjakan, dan semuanya tidak tuntas dikerjakan oleh $M_{2}$, diantaranya adalah soal nomor 1, 2, 3, 4, dan 5. Pemilihan $M_{2}$ sebagai subjek penelitian adalah mewakili dari kelompok kemampuan rata-rata pada kelompok kelas. Adapun soal yang akan dianalisis adalah soal nomor 5. Pemilihan nomor soal tersebut dilakukan dengan alasan bahwa $M_{2}$ memiliki jawaban yang unik. Jadi peneliti ingin mengetahui secara tepat letak kesulitan $M_{2}$ dalam mengerjakan soal nomor 5. Peneliti ingin mengecek apakah memang $M_{2}$ tidak tahu langkah apa yang harus dilakukan untuk memproses jawaban atau ada alasan lainnya.

Setelah diperoleh hasil analisis jawaban tertulis, analisis data wawancara dan observasi, selanjutnya dilakukan perbandingan untuk mengetahui valid tidaknya data yang 
diperoleh. Berikut adalah rangkuman kemampuan pemecahan masalah matematis mahasiswa pada subjek penelitian 2 .

Tabel 2. Triangulasi dari Hasil Jawaban, Wawancara dan Observasi terhadap Subjek Penelitian 2

\begin{tabular}{lll}
\hline Hasil Tes Tertulis & Hasil Wawancara & Hasil Observasi \\
\hline Subjek penelitian & $M_{2}$ kurang teliti dalam & $M_{2}$ telah mencoba \\
mengalami kesulitan pada & menuliskan masalah yang & melakukan langkah \\
tahapan Comprehension, & harus diselesaikann. & Newman, namun keliru \\
dimana $M_{2}$ tidak dapat & & menyatakan hal ditanyakan \\
memahami dengan baik & & dari soal \\
permasalahan yang ada & & \\
\hline
\end{tabular}

\section{Kesimpulan}

Pada soal nomor 5 dapat dibuat kesimpulan bahwa $M_{2}$ sudah mencoba menerapkan prosedur Newman saat mengerjakan soal pemecahan masalah matematika. Namun $M_{2}$ mengalami kesulitan dalam menyelesaikan soal nomor 5 pada tahap Comprehension, dimana $M_{2}$ tidak mengetahui apa yang ditanyakan.

3) Subjek penelitian $3\left(M_{3}\right)$

Subjek penelitian $3\left(M_{3}\right)$ mengerjakan seluruh soal yang diberikan sebanyak 5 butir soal. Pemilihan $M_{3}$ sebagai subjek penelitian adalah mewakili dari kelompok kemampuan rata-rata pada kelompok kelas. Adapun soal yang akan dianalisis adalah soal nomor 3 . Pemilihan nomor soal tersebut dilakukan dengan alasan bahwa $M_{3}$ memiliki jawaban yang unik. Jadi peneliti ingin mengetahui secara tepat letak kesulitan $M_{3}$ dalam mengerjakan soal nomor 3. Peneliti ingin mengecek apakah memang $M_{3}$ tidak tahu langkah apa yang harus dilakukan untuk memproses jawaban atau ada alasan lainnya.

Setelah diperoleh hasil analisis jawaban tertulis, analisis data wawancara dan observasi, selanjutnya dilakukan perbandingan untuk mengetahui valid tidaknya data yang diperoleh. Berikut adalah rangkuman kemampuan pemecahan masalah matematis mahasiswa pada subjek penelitian 3 .

Tabel 3. Triangulasi dari Hasil Jawaban, Wawancara dan Observasi terhadap Subjek Penelitian 3

\begin{tabular}{lll}
\hline Hasil Tes Tertulis & Hasil Wawancara & Hasil Observasi \\
\hline$M_{3}$ telah menuliskan apa & $M_{3}$ memahami masalah yang & $M_{3}$ telah mencoba \\
yang diketahui dan apa & harus diselesaikan dan & melakukan langkah \\
yang ditanyakan tetapi & informasi-informasi yang & Newman, namun \\
$M_{3}$ tidak menulis rumus atau & terdapat di dalam soal. Namun & mengalami kesulitan pada \\
pendekatan yang akan & $M_{3}$ tidak mengetahui rumus & langkah Transformation \\
digunakan untuk & yang harus digunakan untuk & dimana subjek tidak \\
menyelesaikan soal nomor & menyelesaikan soal nomor 3 & sampai menuliskan rumus \\
3., M Mesulitan pada tahap & & yang tepat \\
Transformation & & \\
\hline
\end{tabular}

\section{Kesimpulan}

Pada soal nomor 4 dapat dibuat kesimpulan bahwa $M_{3}$ sudah mencoba menerapkan prosedur Newman saat mengerjakan soal pemecahan masalah matematika. Jenis kesulitan yang dilakukan $M_{3}$ pada soal nomor 3 adalah Transformation.

4) Subjek penelitian $4\left(M_{4}\right)$

Analisis Kesulitan Calon Guru Sekolah Dasar dalam Menyelesaikan Soal Pemecahan ... (Kania \& Arifin) 
Subjek penelitian $4\left(M_{4}\right)$ mengerjakan seluruh soal yang diberikan sebanyak 5 butir soal. Pemilihan $M_{4}$ sebagai subjek penelitian adalah mewakili dari kelompok kemampuan rata-rata pada kelompok kelas. Adapun soal yang akan dianalisis adalah soal nomor 4. Pemilihan nomor soal tersebut dilakukan dengan alasan bahwa $M_{4}$ memiliki jawaban yang unik. Jadi peneliti ingin mengetahui secara tepat letak kesulitan $M_{4}$ dalam mengerjakan soal nomor 4 . Peneliti ingin mengecek apakah memang $M_{4}$ tidak tahu langkah apa yang harus dilakukan untuk memproses jawaban atau ada alasan lainnya.

Setelah diperoleh hasil analisis jawaban tertulis, analisis data wawancara dan observasi, selanjutnya dilakukan perbandingan untuk mengetahui valid tidaknya data yang diperoleh. Berikut adalah rangkuman kemampuan pemecahan masalah matematis mahasiswa pada subjek penelitian 4.

Tabel 4. Triangulasi dari Hasil Jawaban, Wawancara dan Observasi terhadap Subjek Penelitian 4

\begin{tabular}{llrlr}
\hline Hasil Tes Tertulis & Hasil Wawancara & \multicolumn{2}{l}{ Hasil Observasi } \\
\hline Subjek penelitian & Kesulitan pada tahap Process & $M_{4}$ telah & mencoba \\
mengalami kesulitan pada & Skill terjadi karena $M_{4}$ & melakukan & langkah \\
langkah Process Skil. & terburu-buru & dalam & Newman, & namun \\
Dimana $M_{4}$ menggunakan & mengerjakan soal & & mengalami kesulitan pada \\
strategi yang tidak tepat & & & langkah Process Skill \\
\hline
\end{tabular}

\section{Kesimpulan}

Berdasarkan proses triangulasi diperoleh fakta bahwa $M_{4}$ kesulitan pada tahap Process Skill. Adapun kesulitan Process Skill terjadi karena $M_{4}$ kurang teliti dan terburu-buru dalam mengerjakan soal.

\section{5) Subjek penelitian $5\left(M_{5}\right)$}

Subjek penelitian $5\left(M_{5}\right)$ mengerjakan seluruh soal yang diberikan sebanyak 5 butir soal. Pemilihan $M_{5}$ sebagai subjek penelitian adalah mewakili dari kelompok kemampuan rata-rata pada kelompok kelas. Adapun soal yang akan dianalisis adalah soal nomor 2 . Pemilihan nomor soal tersebut dilakukan dengan alasan bahwa $M_{5}$ memiliki jawaban yang unik. Jadi peneliti ingin mengetahui secara tepat letak kesulitan $M_{5}$ dalam mengerjakan soal nomor 2. Peneliti ingin mengecek apakah memang $M_{5}$ tidak tahu langkah apa yang harus dilakukan untuk memproses jawaban atau ada alasan lainnya.

Setelah diperoleh hasil analisis jawaban tertulis, analisis data wawancara dan observasi, selanjutnya dilakukan perbandingan untuk mengetahui valid tidaknya data yang diperoleh. Berikut adalah rangkuman kemampuan pemecahan masalah matematis mahasiswa pada subjek penelitian 5 .

Tabel 5. Triangulasi dari Hasil Jawaban, Wawancara dan Observasi terhadap Subjek Penelitian 5

\begin{tabular}{lll}
\hline Hasil Tes Tertulis & Hasil Wawancara & Hasil Observasi \\
\hline Kesulitan $M_{5}$ dalam & Adapun pada langkah & $M_{5}$ telah mencoba \\
menyelesaikan soal nomor & Encoding memang tidak & melakukan langkah \\
2 terletak pada Encoding. & terjadi kesalahan penulisan & Newman, namun \\
Dimana $M_{5}$ menulis upah & jawaban, tetapi jawaban & mengalami kesulitan pada \\
pertama sebesar5\% dihitung & yang dituliskan bahkan $M_{5}$ & langkah Encoding \\
pada upah bulan pertama, & merasa yakin hasil & \\
sementara di soal & pekerjaannya sudahlah & \\
\hline
\end{tabular}




\begin{tabular}{ll}
\hline disebutkan bahwa pada & benar. Akan tetapi, hasil dari \\
bulan pertama dan & pekerjaannya terdapat \\
seterusnya akan naik & kekeliruan dalam langkah \\
sebesar 5\% dari gaji bulan & Encoding
\end{tabular}

sebelumnya.

\section{Kesimpulan.}

Berdasarkan proses triangulasi diperoleh fakta bahwa $M_{5}$ mengalami kesulitan pada tahap Encoding. Hal ini disebabkan karena $M_{4}$ kurang teliti dan terburu-buru dalam mengerjakan soal.

6) Subjek penelitian $6\left(M_{6}\right)$

Subjek penelitian $6\left(M_{6}\right)$ mengerjakan 3 soal yang diberikan sebanyak 5 butir soal,yaitu; no 2, 4, dan 5. Pemilihan $M_{6}$ sebagai subjek penelitian adalah mewakili dari kelompok yang tidak menggunakan prosedur Newman dalam pemecahannya. Adapun soal yang akan dianalisis adalah soal nomor 2. Pemilihan nomor soal tersebut dilakukan dengan alasan bahwa $M_{6}$ memiliki jawaban yang unik. Jadi peneliti ingin mengetahui secara tepat letak kesulitan $M_{6}$ dalam mengerjakan soal nomor 2. Peneliti ingin mengecek apakah memang $M_{6}$ tidak tahu langkah apa yang harus dilakukan untuk memproses jawaban atau ada alasan lainnya.

Setelah diperoleh hasil analisis jawaban tertulis, analisis data wawancara dan observasi, selanjutnya dilakukan perbandingan untuk mengetahui valid tidaknya data yang diperoleh. Berikut adalah rangkuman kemampuan pemecahan masalah matematis mahasiswa pada subjek penelitian 6 .

Tabel 6. Triangulasi dari Hasil Jawaban, Wawancara dan Observasi terhadap Subjek Penelitian 6

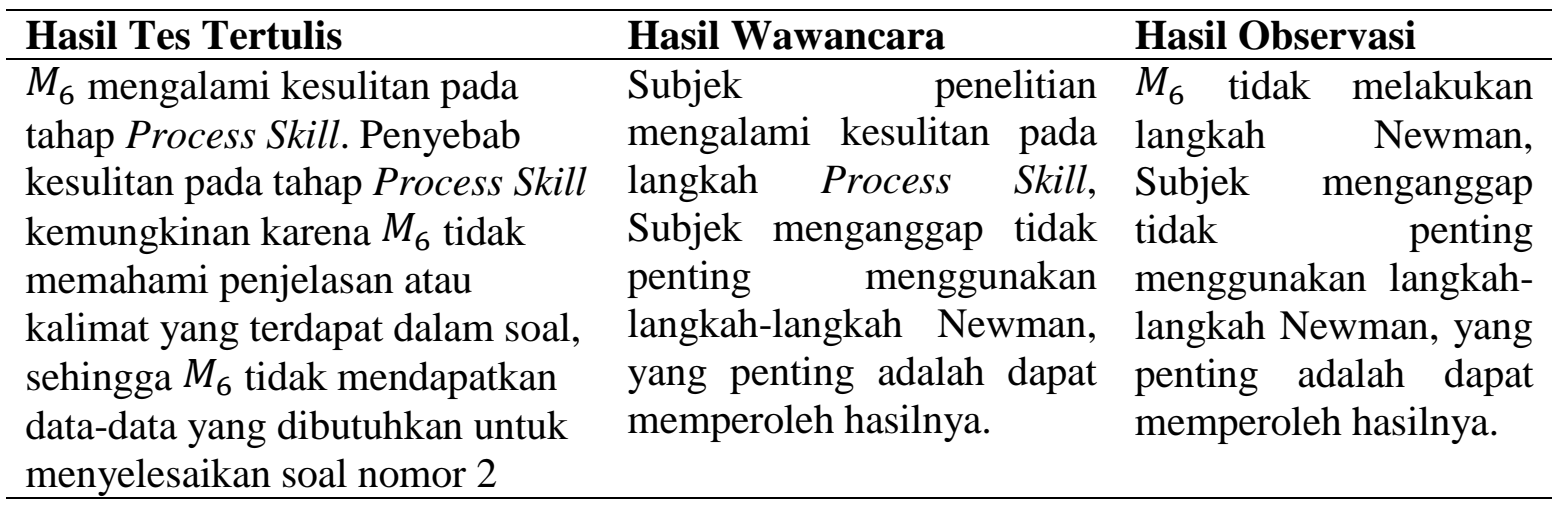

\section{Kesimpulan}

Pada soal nomor 2 dapat dibuat kesimpulan bahwa $M_{6}$ belum menerapkan prosedur Newman saat mengerjakan soal pemecahan masalah matematika. Subjek menganggap tidak penting menggunakan langkah-langkah Newman, yang penting adalah dapat memperoleh hasilnya.

\section{SIMPULAN}

Peningkatan kemampuan komunikasi matematis siswa yang memperoleh model pembelajaran Missouri Mathematics Project (MMP) berbantuan GeoGebra lebih baik dibandingkan dengan peningkatan kemampuan komunikasi matematis siswa yang mendapatkan pembelajaran konvensional. Simpulan yang diperoleh dari penelitian ini 
adalah model pembelajaran Missouri Mathematics Project (MMP) berbantuan GeoGebra lebih efektif dibandingkan dengan pembelajaran konvensional di kelas VIII SMP Negeri 4 Kuningan. Jadi model pembelajaran Missouri Mathematics Project (MMP) berbantuan GeoGebra efektif untuk meningkatkan kemampuan komunikasi matematis siswa SMP. Berdasarkan tahapan kegiatan penelitian yang telah dilaksanakan dapat dikemukakan kesimpulan tahapan penelitian sebagai berikut:

\section{A. Jenis Kesalahan yang dilakukan Mahasiswa Saat Menyelesaikan Soal Pemecahan Masalah dengan Prosedur Newman}

Kesulitan yang dilakukan mahasiswa dalam menyelesaikan soal pemecahan masalah berdasarkan prosedur Newman adalah sebagai berikut.

1) Terdapat $33,33 \%$ subjek penelitian mengalami jenis kesulitan pada tahap comprehension;

2) Terdapat $16,67 \%$ subjek penelitian yang kesulitan pada tahap transformation;

3) Terdapat $16,67 \%$ subjek penelitian yang kesulitan pada tahap process skill;

4) Terdapat $16,67 \%$ subjek penelitian yang kesulitan pada tahap encoding;

5) terdapat $16,67 \%$ subjek penelitian yang tidak menggunakan prosedur Newman dalam menyelesaikan masalahnya.

\section{B. Faktor-Faktor yang Menjadi Penyebab Mahasiswa Mengalami Kesulitan dalam Setiap Langkah Pemecahan Masalah Berdasarkan Prosedur Newman}

Berdasarkan hasil penelitian, beberapa kesulitan yang terjadi; (1) Reading, mahasiswa tidak dapat membaca informasi-informasi yang diberikan dengan mengerti istilah, katakata dan kalimat pada masalah; (2) Comprehension, mahasiswa melakukan kesalahan dalam memaknai masalah apa yang harus diselesaikan dalam soal atau tujuan akhir dari soal setelah dia mampu membaca soal; (3) comprehension disebabkan karena subjek penelitian tidak dapat memahami kalimat yang terdapat dalam soal, dikarenakan tidak terbiasa menyelesaikan soal dengan tipe tersebut, sehingga memerlukan penafsiran dan kurang teliti dalam menuliskan masalah yang harus diselesaikan pada lembar jawab walaupun sebenarnya paham tentang masalah yang harus diselesaikan karena memang sudah jelas tertulis dalam soal; (3) Transformation, disebabkan karena subjek salah dalam menentukan model matematika; (4) Process Skill, disebabkan karena subjek penelitian salah dalam memahami masalah, salah mulai dari proses Transformation, subjek penelitian tidak dapat menentukan model matematika yang tepat; dan kesalahan pada langkah terjadi karena subjek penelitian menggunakan strategi yang tidak tepat; (5) Encoding, disebabkan karena subjek penelitian kurang teliti dalam menyelesaikan soal pemecahan masalah matematika.

\section{Dampak yang ditimbulkan dari Kesulitan Mahasiswa dalam Pemecahan Masalah Matematis}

Adapun dampak yang ditimbukan dari kesulitan mahasiswa PGSD melalui prosedur Newman adalah sebagai berikut:

1) Kesulitan Reading, dampak yang ditimbulkan dari kesulitan ini adalah mahasiswa tidak dapat mengetahui apa yang diketahui dan apa yang ditanyakan dari soal tersebut.

2) Kesulitan Comprehension, akan berdampak mahasiswa tidak dapat menentukan apa yang diketahui dan apa yang ditanyakan dengan tepat

3) Kesulitan Transformation, akan berakibat mahasiswa tidak memiliki rencana 
pemecahan masalah yang relevan dengan masalah yang diberikan

4) Kesulitan Process Skill, akan berakibat mahasiswa tidak dapat memecahakan masalah sesuai dengan langkah-langkah pemecahan masalah secara tepat sesuai yang telah direncanakan pada tahap transformation

5) Kesulitan Encoding, akan mengakibatkan mahasiswa tidak dapat melakukan pegecekan dan memberikan kesimpulan terhadap pemecahan masalah.

\section{Cara Mengatasi Kesalahan Mahasiswa dalam Pemecahan Masalah Matematis}

Adapun cara mengatasi kesalahan mahasiswa dalam pemecahan masalah matematis mahasiswa PGSD melalui prosedur Newman adalah sebagai berikut;

1) Reading, mahasiswa hendaknya lebih teliti dalam membaca soal dan kalau perlu membaca ulang soal agar tidak ada informasi yang nantinya dibutuhkan yang akan terlewat. Selain itu mahasiswa juga diharapkan memiliki pengetahuan yang cukup tentang materi matematika.

2) Comprehension, dosen hendaknya lebih sering dalam memberikan soal-soal pemecahan masalah yang membutuhkan penafsiran kebahasaan agar mahasiswa terbiasa dengan kondisi tersebut. Selain itu, mahasiswa juga hendaknya rajin berlatih mengerjakan soal-soal yang diberikan oleh dosen maupun berusaha mencari sendiri agar keterampilan penafsiran kebahasaannya bagus.

3) Transformation, saat proses perkuliahan, dosen hendaknya memastikan bahwa mahasiswa memaha mimateri dan rumus-rumus yang akan digunakan untuk menyelesaikan soal-soal.

4) Process Skill, mahasiswa harus benar-benar sudah memahami masalah yang harus diselesaikan. Jika masalah yang dipahami benar, kemungkinan langkah process skill mereka juga tidak akan terlalu jauh dari prosedur.

5) Encoding, mahasiswa untuk mengecek kembali lembar pekerjaannya sebelum dikumpulkan, sehingga tidak ada sesuatu yang salah dia tulis pada lembar jawaban.

\section{DAFTAR PUSTAKA}

Abdullah, S. (2000). Memecahkan Masalah dalam Matematika. Jurnal Gentengkali, 3(1), 36-39.

Alam, N., \& Pathuddin. (2002). Pemecahan Masalah dalam Matematika. Kreatif, Jurnal Pendidikan dan Seni, 5(3), 59-72.

Bahar, A.K. (2015). Cognitive Background of Problem Solving: A Comparison of Openended vs. Closed Mathematics Problems. Eurasia Journal of Mathematics, Science \& Technology Education, 11(6), 1531-1546.

BSNP. (2006). Standar Kompetensi dan Kompetensi Dasar Tingkat SD, MI, dan SLBSD. Jakarta: BSNP.

IMSTEP-JICA. (1999). Permasalahan Pembelajaran Matematika SD, SMP, SMU di Kota Bandung. Bandung: FMIPA UPI.

Mulllis, et al. (2011). TIMSS: Trends in Mathematics anf Science Study: Assessment Speciafication 2006. Boston: The International Study Center.

NCTM. (1980). Problem Solving in School Mathematics. Yearbook: NCTM Inc.

OECD. (2013). PISA 2012 Result: What Student Know and Can Do Student Performance in Mathematics, Reading and Science (Volume I). [Online]. Tersedia: http://www.oecd.org/pisa/keyfindings/pisa-2012-results-volume-I.pdf. 
Sugiyono. (2013). Metode Penelitian Kuantitatif, Kualitatif dan Kombinasi (Mixed

Methods). Bandung: Alfabeta.

Turmudi. (2008). Landasan Filsafat dan Teori Pembelajaran Matematika: Paradigma Eksploratif dan Investigatif. Jakarta: Leuser Cita Pustaka.

\title{
Elementary School Teacher Candidates' Difficulties on Solving Mathematical Problem Based on Newman's Procedure
}

\author{
Nia Kania \\ Department of Mathematics Education, Universitas Majalengka, Majalengka, Indonesia \\ niakania@unma.ac.id \\ Zaenal Arifin * \\ Department of Mathematics Education, Universitas Majalengka, Majalengka, Indonesia \\ *Corresponding Author, zaenalarifin@unma.ac.id
}

\begin{abstract}
The purpose of this research was to; (1) overview the student profile in solving mathematical problems on the Newman procedure; (2) Describe the factors that cause students difficulties in every step in solving mathematical problems on the Newman procedure; (3) Describe impact of student difficulties in mathematical problem solving; (4) Find the solution to overcome student errors in mathematical problem solving. The population in this research is elementary teacher candidates of grade Vof Universitas Majalengka. Data is collected obtained by the test observation and interview. The results of the analysis in this research are (1) There are 33,33\% research subject who does reading error difficulties; (2) There are $16,67 \%$ of research subjects who do transformation difficulties; (4) There are $16,67 \%$ research subjects who do process skill difficulties; (5) There $16,67 \%$ research subjects who do coding difficulties; (6) There are $16,67 \%$ research subjects who do not use the Newman procedure.
\end{abstract}

Keywords: Difficulty of Elementary Teacher Candidates, Newman Procedure, Mathematical Problem Solving. 